\title{
Neprispôsobiví Rómovia a slušná väčšina? Spravodajský diskurz po násilných udalostiach na severe Českej republiky $2011^{1}$
}

\author{
Alena Kluknavská, Lenka Zagibová ${ }^{2}$
}

\begin{abstract}
Unadaptable Roma and Decent Majority? News Discourse After the 2011 Violent Incidents in the North Part of the Czech Republic

The paper analyses the news discourse on Roma minority during the violent incidents and the following anti-Roma protests in the north part of the Crech Republic in 2011. It focuses on news reports relating to the Roma in three most-read Czech newspapers between August 8, 2011 and September 8, 2011. The study adheres to the discourse analysis and is undertaken in three stages. In first step we introduce a general characterization of the news and the context of the unrests as presented by the media. This is followed by the analysis of the extent to which the media emphasize the ethnicity and generalize the "Roma" criminality. In third step a dichotomy in relation to the majority and the Roma minority (us vs. them) is analysed. The analysis points to systematic ,othering" and stereotyping of Roma minority in the selected newspapers. Results show that the media emphasized the ethnicity of Roma actors involved in the attacks and generalized given incidents as continuing „Roma" criminality. Moreover, the newspapers tended to present the situation either as "the last drop" of the tensions between two groups (majority population and Roma minority) or as a consequence of the problems with the criminality of ",unadaptable" citizens, meaning the Roma. These discursive practices can lead to deepening of racial stereotypes in the society, but they can also contribute to the formation of favourable discoursive opportunity structure, hence favourable context for parties of the far right, which are characteristic of their nationalistic, racist and xenophobic rhetoric and actions.
\end{abstract}

Key words: Ethnic minorities, Roma, news discourse, discourse analysis, media, newspapers

\section{1. Úvod}

Začiatkom augusta 2011 došlo v bare v severočeskom meste Nový Bor k sporu medzi servírkou a dvojicou neplnoletých mladíkov pre hracie automaty. Po tom, čo sa niekol'kí hostia postavili na stranu barmanky, mladíci podnik opustili, avšak vzápätí sa vrátili s tromi d’alšími mužmi a fyzicky napadli hostí za použitia predmetov ako mačety, tyče a obušky. Polícia obvinila piatich mužov z výtržníctva, z toho štyroch tiež z pokusu o vraždu. Médiá krátko po udalosti začali intenzívne informovat' o rôznych aspektoch prípadu a incident označili za mačetový útok a obvinených za mačetových útočníkov. O dva týždne neskôr došlo v len niekol'ko kilometrov vzdialenom Rumburku k fyzickému stretu medzi dvomi skupinami mladých mužov, kedy podl’a mediálne dostupných informácií mali Rómovia vracajúci sa z diskotéky bez príčiny brutálne zbit' miestnych bielych chlapcov.

\footnotetext{
1 Táto práca bola podporovaná Grantom pre doktorandov a mladých vedeckých pracovníkov Univerzity Komenského č. G-13-067-00.

2 Korešpondenčná adresa: Alena Kluknavská, Lenka Zagibová, Katedra politológie, Filozofická fakulta Univerzity Komenského, Gondova 2, 811 02, Bratislava, Slovenská republika; e-mail: alena.kluknavska@uniba.sk, lzagibova@gmail.com.
} 
Oba incidenty spustili sériu protirómskych protestov a demonštrácií v oblasti Šluknovska v severných Čechách, ktoré organizovali obyvatelia prostredníctvom sociálnych sietí, ale aj miestna Česká strana sociálně demokratická a krajne pravicoví aktéri, vrátane zástupcov Dělnickej strany sociální spravedlnosti (DSSS). Médiá informovali o spustení potlačovanej zloby a frustrácie miestnych obyvatel'ov (e.g. iDnes.cz 2011) a krajná pravica sa snažila rámcovat' nepokoje ako stupňujúce sa „cigánske násilie“ a ohrozovanie „slušných l’udí, ktorí sú vydaní na milost’ a nemilost’ vyčíňaniu neprispôsobivých gaunerov“ (DSSS 2011). Na druhej strane, podl’a jednej z advokátok obvinených $\mathrm{v}$ prípade $\mathrm{v}$ Novom Bore bol incident „vyvrcholením minimálne pätnást' rokov trvajúceho konfliktu medzi novoborskými Rómami a novoborskými, prípadne českolipskými obdivovatel'mi skinheadského hnutia“" (Samková 2012).

Hoci v sčítaní l'udu z roku 2011 sa prihlásilo k rómskej národnosti len 13150 obyvatel’ov (Český statistický úřad 2011), ako poznamenali Vano a Haviarová (2002: 475), kým príslušníci ostatných etnických skupín sa obvykle hlásia k národnosti podl’a etnickej príslušnosti, väčšina Rómov si volí inú národnost'. Napriek tomu, že v súčasnosti neexistujú oficiálne štatistické údaje o etnickom zložení obyvatel'stva, na území Českej republiky sa vel'kost' rómskej populácie odhaduje na 200-tisíc až 250-tisíc (Koncept rómskej integrácie pre 2010-2013 v ČR 2009; Liégeois 2008; Rada Európy $2012^{3}$ ). Pod pojmom Róm pritom môžeme identifikovat' viacero etnických skupín s rôznym historickým pôvodom a rôznymi pomenovaniami ako Róm, Cigán, Sinti, Romaničel, ale aj kočovník (tzv. „Traveller“, pojem využívaný najmä na území Vel’kej Británie). Róm je pre účely práce definovaný ako občan, ktorý je za Róma (alebo Cigána, atd’) označený v rámci novinového spravodajstva, a to bud' médiami/reportérmi alebo aktérmi (citovanými zdrojmi), ktorí v správach vystupujú (napr. politické, právne, verejné autority; členovia majoritného a minoritného obyvatel'stva, atd’.). Využívaním pojmu nechceme podcenit' rôznorodost' rómskych skupín a komunít, práve naopak, pomocou analýzy chceme zistit', akými pomenovaniami je táto skupina v Českej republike označovaná $\mathrm{v}$ rámci mediálneho diskurzu.

Vzt’ahy spolužitia Rómov a väčšinového obyvatel'stva sú podl'a opakovaných verejných prieskumov výraznou väčšinou vnímané ako problematické. V roku 2011 až 81 percent opýtaných označilo vzt’ahy za zlé (za dobré 16 percent), pričom v priebehu rokov sa hodnotenie postupne zhoršovalo. Kým v roku 1999 považovalo vzájomné spolužitie za zlé 66 percent opýtaných, v roku 2013 už 87 percent respondentov. Naopak, vnímanie dobrých vzt’ahov kleslo z 23 percent v roku 1999 na 9 percent v roku 2013 (CVVM 2013). Tieto nálady sa na získanie voličskej podpory okrem mainstreamových politických strán snažia využit' krajne pravicoví aktéri. V oblasti strednej a východnej Európy sú xenofóbne nálady a kampane krajne pravicových strán namierené najmä práve voči rómskej menšine (Kluknavská 2013). Krajne pravicová DSSS hovorí o probléme „sociálne neprispôsobivých parazitov“ (DSSS 2013a), ked” „ochrana menšín v Českej republike dosiahla naprosto absurdné rozmery, kedy sú neprispôsobiví občania postavení do privilegovanej vrstvy“ (DSSS 2013b).

\footnotetext{
3 Podl’a Konceptu rómskej integrácie pre 2010-2013 v Českej republike, ktorý bol vytvorený v súvislosti s Rámcom EÚ pre vnútroštátne stratégie integrácie Rómov do roku 2020, sa počet Rómov v ČR odhaduje na 150-200-tisíc. Rada Európy zase odhaduje počet Rómov v krajine na 150-250 tisíc, čo je v priemerne približne 1,9 percenta populácie ČR. Podobný údaj - 200-250-tisíc - udáva aj Liégeois (2008: 31).
} 
Zobrazovanie skupín etnických menšín v médiách podl'a Bobo (1997: 7) z vel'kej časti “reflektuje a tvaruje postoje a presvedčenie l’udí o týchto skupinách". Masové médiá poskytujú vel'kú čast' informácií, ktoré slúžia na vytvorenie obrazu o svete okolo (Bennet, Entman 2001), avšak pre selekciu a rozhodovanie, o čom budú alebo nebudú informovat', nevyhnutne zobrazujú o svete skreslený obraz. Preto je potrebné zistit', či mediálne prostredie podporuje alebo odrádza stereotypné uvažovanie o tých, ktorí sú často vel'mi vzdialení od každodenných rutín mnohých príslušníkov majority. Navyše, médiá môžu zdôrazňovaním protirómskych nálad prispiet’ k vytvoreniu pozitívne naklonených tzv. štruktúr diskurzívnych príležitostí pre krajne pravicové strany, teda k vytvoreniu prostredia, v ktorom majú radikálne myšlienky priestor, rezonanciu a legitimitu na uplatnenie sa (Koopmans, Olzak 2004). Doterajší výskum ukazuje, že novinári často vytvárajú rámec, v ktorom sú menšinám pripisované negatívne charakteristiky, prehlbujú existujúce schémy a opisujú príslušníkov etnických menšín ako problémové skupiny a páchatel'ov kriminálnej činnosti (Teo 2000; Larson 2005). Médiá tak môžu zohrávat’ významnú úlohu pri formovaní priestoru týchto subjektov na politickej scéne (Ellinas 2010).

V príspevku sa snažíme odpovedat' na otázku, akým spôsobom boli Rómovia prezentovaní v troch najčítanejších českých denníkoch v období od 8. augusta do 8. septembra 2011 v súvislosti s incidentmi $\mathrm{v}$ českých mestách Nový Bor a Rumburk a následnými protestmi, ktoré po týchto udalostiach nasledovali. Ciel'om práce je analyzovat' prevládajúci spravodajský diskurz v súvislosti s rómskou menšinou, teda spôsob, akým denníky konštruovali obraz Rómov. Získané dáta analyzujeme prostredníctvom diskurzívnej analýzy, ktorá sa vo všeobecnosti venuje skúmaniu ludskej komunikácie v rôznych formách. Mediálny diskurz je kultúrnym a spoločenským produktom, v rámci ktorého sa prejavujú a reprodukujú významy a ideológie (van Dijk 1992). V článku skúmame konflikt, ktorého spúšt'ačom bola násilná udalost', kde vystupovali Rómovia ako obvinení páchatelia, a tak je možné predpokladat' zobrazovanie spojenia medzi násilným správaním a danými Rómami. Pri skúmaní sa však neobmedzujeme len na bitku v Novom Bore, ale analyzujeme aj následné udalosti a zobrazovanie rómskej menšiny ako takej, kde možno pri sledovaní kontextu pozorovat' celkovú podobu spravodajského diskurzu.

Práca je členená do piatich častí. Najskôr predstavíme prehl’ad podôb a vplyvov mediálnych diskurzov etnických menšín z doterajších poznatkov v oblasti zahraničného a domáceho výskumu. Pri predstavení výskumov zobrazovania etnických menšín v masových médiách sa zameriavame na závery diskurzívnych analýz a v prípade domácich analýz pre menší počet diskurzívnych analýz aj výsledky d’alších kvalitatívnych výskumov. $\mathrm{V}$ d’alších častiach predstavíme teoreticko-metodologický rámec diskurzívnej analýzy a ukážeme spôsoby zberu dát a postup analýzy, ktorú uplatňujeme pri skúmaní. V d’alšej časti predstavíme výsledky a v závere sumarizujeme a diskutujeme zistenia a ich možné implikácie pre d’alší výskum.

\section{Podoby a vplyvy diskurzu etnických menšín v spravodajstve masových médií}

Médiá vytvárajú jednu $\mathrm{z}$ najviditel'nejších a najdôležitejších arén na konštruovanie sociálnych a politických identít a realít. Ked’že spôsob, akým sú l’udia prezentovaní v médiách, má reálne dopady na ich životy, práva a pozície v spoločnosti (Hall 1997), sila médií tkvie najmä v ich schopnosti prispiet' k selekcii toho, čo a akým spôsobom l’udia okolo seba vidia a vnímajú (Pietikainen 2003). 
Médiá môžu týmto spôsobom prispievat' $\mathrm{k}$ vytvoreniu priaznivých štruktúr diskurzínnych priležitostí (Koopmans, Statham 1999), v rámci ktorých majú isté myšlienky, napríklad radikálne rámce vytvárané krajne pravicovými aktérmi, šancu na úspešné rozptýlenie vo verejnom diskurze a v rámci ktorých budú považované za reálne a legitímne (Koopmans, Olzak 2004).

V zahraničných, aj českých štúdiách mediálnej prezentácie menšín sa opakuje niekol’ko záverov. Ide predovšetkým o zdôrazňovanie delenia spoločnosti na väčšinu a menšinu, teda dichotómne delenie spoločnosti na „nás“ a „tých druhých“, zdôrazňovanie kriminality a násilia, a malý priestor poskytovaný predstavitel’om menšín. Takýto rámec, v ktorom sú príslušníkom menšín stereotypným spôsobom pripisované negatívne charakteristiky a vktorom sú tieto menšiny opisované ako problémové skupiny a páchatelia kriminálnej činnosti, môže mat’ na spoločenské a politické procesy dva navzájom súvisiace vplyvy. Mediálne diskurzy môžu stereotypizáciou a zdôrazňovaním protirómskych nálad jednak prispievat’ k predsudkom a negatívnym náladám majoritnej spoločnosti voči danej menšine a vytvárat' celospoločenskú averziu a a priori nepriatel'stvo voči príslušníkom menšiny na základe ich etnického pôvodu, a jednak vytvorit' priaznivé diskurzívne príležitosti, teda diskurzívny kontext naklonený krajne pravicovým aktérom, čím v konečnom dôsledku môžu prispiet' k ich úspechu na politickej scéne.

Koopmans a Muis (2009) analyzovali prostredníctvom prístupu štruktúr diskurzívnych príležitostí výrazný nárast volebných preferencií krajne pravicovej strany Pima Fortuyna počas kampane k parlamentným vol’bám 2002 v Holandsku. Zistili, že negatívne vyjadrenia rôznych politických aktérov ohladom imigrácie a integrácie v médiách zvýšili šance tohto lídra na rozptýlenie jeho názorov vo verejnom diskurze (a získanie väčšieho mediálneho priestoru) a na dosiahnutie podpory medzi holandskými voličmi. Wodak a Pelinka (2002: 197) tiež tvrdia, že po tom, čo sa Jörg Haider stal v roku 1986 lídrom rakúskej krajne pravicovej strany Freiheitliche Partei Österreichs (FPÖ), najväčší rakúsky bulvárny denník Kronen Zeitung začal podporovat' Haiderov pohlad na "problém s cudzincami” a anti-imigrantskú iniciatívu. Podl’a Plassera a Ulrama (2003) otázka imigrácie a jej dopad na spoločnost' boli vnímané s väčšou emocionalitou a strachom čitatel'mi denníka Kronen Zeitung než čitatel'mi iných novín, čo u prvej skupiny prispelo ku skeptickým postojom voči tradičným politickým stranám a ku väčším sympatiám voči krajne pravicovej FPÖ. Ellinas (2010: 73) zase tvrdí, že jedným z faktorov, ktoré prispeli k volebnému neúspechu strany vo vol'bách 2004, bola zmena postoja denníka voči Haiderovi, ked’ „po tom, čo FPÖ vstúpilo do vlády, noviny stiahli svoju tichú podporu“. Podl’a Eatwella (2003) sú médiá vo všeobecnosti negatívne naladené voči extrémistickým prejavom, no priamo aj nepriamo môžu podporovat' témy blízke krajnej pravici a prispievat' tak $\mathrm{k}$ predsudkom $\mathrm{v}$ spoločnosti a vytváraniu vhodných štruktúr na prienik krajne pravicových strán do politického systému.

Zahraničné analýzy prezentácie etnických menšín v médiách dospievajú väčšinou k záverom, že masové médiá poskytujú o etnických menšinách stereotypný, až negatívny obraz. Van Dijk (1991; 1992), ktorý bol priekopníkom kritických diskurzívnych analýz, tvrdí, že etnické minority zvyknú byt' v médiách prezentované niekedy až rasistickým spôsobom ako cudzí element a hrozba. Mediálne diskurzy tak môžu prispievat' $\mathrm{k}$ predsudkom a rasistickým tendenciám majoritnej spoločnosti a k problematizovaniu postavenia minorít v spoločnosti. Médiá často zobrazujú etnické menšiny spôsobom, ktorý podporuje „nepriame, diskriminačné spoločenské praktiky založené na negatívnych postojoch o tých druhých“ (van Dijk 2006: 61) a zvyknú sa zameriavat’ na imigračné problémy, 
deviácie, kriminalitu a násilie, etnické vzt'ahy a (skutočné alebo domnelé, ale negatívne interpretované) kultúrne rozdiely (van Dijk 1992).

Médiá často zdôrazňujú príslušnost' páchatel’ov kriminálnej činnosti k etnickej menšine, kým „bielych“ prezentujú ako tých, ktorí právo zabezpečujú (Teo 2000). Teo (2000) na prípade zobrazovania vietnamského drogového gangu 5T v austrálskych denníkoch ukázal stereotypizáciu vietnamskej komunity a systematické vyčleňovanie jej členov ako „tých druhých“, kedy dochádzalo ku generalizácii kriminality jednotlivých Vietnamcov na všetkých l’udí s ázijským pôvodom. Niektoré diskurzívne analýzy mediálneho spravodajstva tiež ukazujú, že etnické minority nie sú zobrazované len ako problémové skupiny, ale aj ako devianti vo vzt’ahu k spoločenským normám a hodnotám majority, prípadne ich identita je prezentovaná ako marginálna $\mathrm{k}$ identite väčšiny, čo prispieva $\mathrm{k}$ ich marginalizácii vo verejnom diskurze (Pietikäinen, Hujanen 2003).

$\mathrm{V}$ mediálnych obsahoch je tiež často prítomné delenie spoločnosti na dve skupiny, menšinu a väčšinu, pričom majorita máva v tomto vzt’ahu dominantné postavenie (e.g. van Dijk 2006). Zdrojmi informácií bývajú najmä autority, málokedy členovia menšinovej komunity, ktorí aj v prípade, že citovaní sú, bývajú definovaní svojou príslušnost’ou k minorite (Teo 2000; Kim 2012). Richardson (2004), ktorý analyzoval zobrazovanie moslimov v britskej tlači, tvrdí, že hranice rozlišovania medzi „nami““ a „nimi““ nemusia byt’ explicitne vytýčené; v textoch, ktoré skúmal, tieto hranice naznačoval pocit určitej nadradenosti a národnej hrdosti a zdôrazňovanie rozdielov medzi islamom a západom.

Z analýz zobrazovania etnických menšín v českých médiách vyplýva, že menšinám a cudzincom nie je venovaný dostatočný priestor na vyjadrenie, správy bývajú vytrhnuté z kontextu, pričom sa často sústred'ujú na kriminálnu činnost', a aj v prípadoch, ked' sa snažia pôsobit' pozitívne, často podporujú stereotypy a výsledný obraz pôsobí zavádzajúco a povrchne. Podl’a rozsiahlej analýzy (júl 2011 - máj 2012) mediálneho zobrazenia Rómov (Křřžková 2012) je možné sledovat’ dve tendencie, a to negatívny stereotypný obraz rómskej komunity a výrazne slabší trend nastol'ovania alternatívy $\mathrm{k}$ danému stereotypu. $\mathrm{V}$ analyzovanom spravodajstve bolo prítomné nadužívanie etnickej príslušnosti a prevládal dominantný obraz konštrukcie „rómskej“ kriminality, obavy majority z Rómov, požiadavky na zaistenie bezpečia a vytváranie obrazu problematického spolužitia majority a minority (Kř́ržková 2012).

Podl’a zistení viacerých autorov (Klvačová, Bitrich 2003; Křížková 2007; Tejkalová, Láb et al. 2009) v spravodajstve českých denníkov a týždenníkov taktiež často absentujú vyjadrenia príslušníkov menšín alebo cudzincov, ktorých sa správy týkajú, nie sú riadne citovaní alebo im je daný len minimálny priestor na vyjadrenie. O menšinách, cudzincoch a migrantoch sa často píše ako o homogénnej mase alebo štatistickom údaji. Hovorca býva často nešpecifikovaný a chýba odôvodnenie, na základe čoho hovorí za celú komunitu, prípadne nie je uvedený zdroj a novinári využívajú len kolektívne pomenovania ako Rómovia tvrdia, Rómovia chcú (Tejkalová, Láb et al. 2009). $\mathrm{V}$ prípade, že sa médiá jednotlivcom venujú, býva to spravidla v negatívnych prípadoch, akými sú vyhostenia alebo zločiny (Klvaňová 2007; Klvačová, Bitrich 2003). Výnimku tvoria tzv. l'udské príbehy, ktoré na jednej strane môžu približit' napríklad život v rómskej osade alebo problémy s hladaním práce, na druhej strane z nich niekedy recipient môže získat' dojem, že prezentovaní jedinci sú skôr výnimka, a stereotypy sú tak väčšmi upevňované než potláčané (Klvačová, Bitrich 2003). V médiách tiež často chýba snaha o uvedenie čitatel’a do historického, kultúrneho alebo iného kontextu, kedy sa menšinový aktér „vel’mi často stáva v článku pasívnym a dekontextualizovaným 
objektom“ (Kř́žzová 2007: 18).

Etnické menšiny sú v českých médiách často zobrazované v súvislosti s kriminálnou činnost'ou (Klvačová, Bitrich 2003; Nekvapil, Leudar 2003; Badáňová 2010; Křížková 2007). Nekvapil a Leudar (2003) skúmali, ako bezprostredne po vzniku Českej republiky v roku 1993 bola v českých médiách v súvislosti s tzv. migračným zákonom prezentovaná rómska tematika a zistili, že argumentácia aktérov prezentujúcich zákon vychádzala z predpokladu, že Rómovia sú spojení s kriminálnymi aktivitami, prípadne, že sú príčinou spoločenského nepokoja. Badáňová (2010) tiež zistila, že ak boli páchatelia trestných činov rómskeho pôvodu, bola zdôrazňovaná ich etnicita a nízky vek, používané negatívne expresívne výrazy alebo neboli uvádzané možné dôvody trestných činov.

\section{Diskurz a diskurzívna analýza}

Vo väčšine prístupov je diskurz chápaný ako sociálna praktika (e. g. Wodak 2008), ktorej hlavnou premisou je idea, že spôsob, akým hovoríme, nie je neutrálnou reflexiou sveta, spoločenských vzt’ahov a identít, ale hrá aktívnu rolu vo vytváraní a pozmeňovaní týchto entít. Diskurz tak nie je len prostriedok $\mathrm{k}$ pochopeniu sociálnej reality, ale pomáha túto realitu budovat', mení sa podl’a situácie a adresáta a buduje verziu sveta, ktorá je konfrontovaná s inými verziami. Diskurzy, vzorce jazyka, ktoré sa vyskytujú v textoch a konverzáciách, sú tak spoločensky konštituované aj spoločensky podmienené. Konštruujú situácie, objekty poznania, identity a vzt’ahy medzi l'ud'mi a skupinami l’udí - pomáhajú im udržiavat' a reprodukovat' spoločenské status quo, ale zároveň tiež prispievajú k ich transformácii. Mediálny diskurz je pritom jedným zo zdrojov, ktoré l’udia využívajú na pochopenie rôznych tém a na komunikáciu o týchto témach (Gamson 1992).

Vznik súčasnej diskurzívnej analýzy je spojený so zmenami v sociálnych vedách v 60. a 70. rokoch 20. storočia, kedy v rámci lingvistiky vzniklo niekol'ko nových interdisciplín, medzi inými diskurzívna analýza (van Dijk 2007). Tá sa odlišila od iných disciplín zameraním na väčšie lingvistické celky než izolované vety (Gamson 1992; Alba - Juez 2009) a pozornost’ou, ktorú venuje kontextom, $\mathrm{v}$ ktorých diskurz vzniká, $\mathrm{v}$ ktorých je prezentovaný a ktorý je zároveň prezentovaný $\mathrm{v}$ jeho rámci (Wodak 2008). Diskurzívna analýza je v tomto zmysle analýza vzorcov jazyka a kontextu, v ktorom sa text používa. Van Dijk vo svojich prácach (e. g. 1992) zdôraznil výhodnost' diskurzívnej analýzy práve pri štúdiu predsudkov a rasizmu. Podl’a jeho tvrdenia diskurz hrá v produkcii a reprodukcii predsudkov a rasizmu dôležitú úlohu, a to vytváraním mentálnych modelov, formovaním spoločenského poznania, postojov a ideológí, ktoré kontrolujú l’udské konanie (van Dijk 1992).

Pomocou diskurzívnej analýzy možno nazerat' na základné vzt’ahy v spoločenských vedách a na úlohu jazyka v sociálnom konštruovaní sveta. Diskurzívna analýza však nepredstavuje jednotný ucelený prístup, ale zahŕňa viaceré metodologické perspektívy, ktoré spájajú lingvistické a interpretačné metódy. A tak hoci ontologické, epistemologické a metodologické predpoklady diskurzívnej analýzy vytvárajú integrovaný celok, je možné kombinovat' diskurzívne elementy jednotlivých aspektov. Takúto kombináciu využívame aj v našej práci. Blanche a Durrheim (1999) identifikovali pomôcky na identifikáciu diskurzívnych vzorcov - napríklad hladanie binárnych protikladov, identifikovanie opakujúcich sa termínov, fráz, metafor (každý diskurz má určitý spôsob hovorenia, ktorý zahŕňa obsah vypovedaného, aj spôsob, akým to bolo vypovedané a kontext, 
v ktorom to bolo vypovedané), prípadne identifikovanie subjektov, o ktorých sa v texte hovorí. Techniku, ktorú využívame v článku, bližšie rozoberáme v nasledujúcej časti.

\section{Metodológia}

V príspevku na vybranom prípade skúmame mediálny diskurz rómskej menšiny v českých denníkoch v súvislosti s násilnými a protestnými udalost’ami v auguste 2011 na severe Českej republiky. Hoci nepokoje v oblasti Šluknovska pokračovali aj počas d'alších mesiacov, najmä v susednom meste Varnsdorf, kde sa konalo viacero protirómskych demonštrácií, práca sa týmto nadväzným udalostiam nevenovala. Jej ciel'om bolo híbkovo zachytit' spravodajský diskurz udalostí, ktoré boli prezentované ako spúšt’ač napätia a nepokojov, teda obdobia dvoch útokov v mestách Nový Bor a Rumburk. V článku pracujeme s dvomi tézami, ktoré sme si stanovili na základe výskumov zobrazovania etnických menšín v médiách v zahraničí a v Českej republike. Po prvé, predpokladáme, že vo vybraných médiách bude zdôrazňovaná etnicita rómskych účastníkov konfliktov a rómska menšina bude a priori spájaná s kriminálnym alebo násilným konaním, pričom názory a konanie jednotlivcov budú zároveň prenášané na celú menšinu. Po druhé, v sledovaných denníkoch bude prítomné delenie spoločnosti na majoritnú a minoritnú čast', pričom bude zdôrazňovaná existencia napätia medzi dvoma skupinami.

Pre analýzu sme si vybrali obdobie jedného mesiaca, od 8. augusta do 8. septembra 2011 v troch najčítanejších českých denníkoch Blesk, MF Dnes a Právo. Blesk je podl’a odhadovanej dennej čítanosti Unie vydavatelů (2011) dlhodobo najčítanejším denníkom v ČR, MF Dnes je na druhom mieste a Právo na tret'om mieste. Denník Blesk dosiahol odhadovanú priemernú dennú čítanost' v tret'om a štvrtom štvrt'roku 2011 celkovo 1,29 milióna čitatel’ov, MF Dnes 797-tisíc a Právo 395tisíc čitatelov (Unie vydavatelů 2011) ${ }^{4}$. Pracovali sme s tlačenými verziami denníkov a skúmali sme celé čísla novín, spolu 81 výtlačkov, z ktorých sme vyselektovali všetky spravodajské príspevky, ktorých hlavnou alebo vedl'ajšou témou boli incidenty v Novom Bore (7. august 2011) a Rumburku (21. august 2011) alebo následné protesty a správy o sociálnom a etnickom napätí v oblasti, a v ktorých sa spomínala niektorá podoba pojmu Róm. Nášho výskumného problému sa týkalo 74 spravodajských príspevkov, z ktorých v Práve vyšlo 30, v MF Dnes 23 a v Blesku 21 príspevkov.

V práci sme vychádzali z diskurzívnej analýzy, ktorá za základnú jednotku považuje celú výpoved', v prípade našej práce jeden spravodajský príspevok, a ktorá vo svojej komplexnosti využíva kombinovatel'né postupy. V prvom kroku analýzy sme spracovali kontextový prehlad správ - venovali sme sa charakteristickým črtám, rozsahu a umiestneniu správ v rámci vydania. Zároveň sme identifikovali súvislosti, ktoré denníky zdôrazňovali a ktoré naopak marginalizovali, prípadne úplne opomenuli, a časový rámec a kontext udalostí - zist'ovali sme najmä to, či sledované incidenty boli dávané do súvislosti s inými incidentmi, napríklad inou trestnou činnost'ou, a aké charakteristické vlastnosti denníky Rómom pripisovali.

4 V auguste 2011 patrili dané tituly vzhl’adom na predaný náklad zároveň k najpredávanejším českým denníkom (s výnimkou denníka Deník, ktorý bol s priemerným denným predaným nákladom 202424 výtlačkov tretím najpredávanejším denníkom) - Blesk dosiahol predaný náklad 345229 výtlačkov, MF Dnes 221805 výtlačkov a Právo 121609 výtlačkov (ABC CR 2011). 
V druhom kroku sme sa zamerali na mieru zdôrazñovania etnicity a generalizáciu „rómskej" kriminality. Generalizácia odkazuje na rozšírenie charakteristík alebo konania špecifickej skupiny alebo jednotlivcov na širšiu a všeobecnejšiu skupinu. $\mathrm{Na}$ jednej strane predstavuje generalizácia pre novinárov výhodný spôsob, ako pripísat' isté vlastnosti aktérom spravodajského diskurzu bez toho, aby museli zachádzat' do zdíhavých opisov. Na strane druhej selekcia a reprodukcia určitých zovšeobecňujúcich prvkov naznačuje implicitnú ideológiu motivujúcu novinára k výberu daného zovšeobecnenia. V práci sme si preto všímali opisy a charakteristiky rómskych účastníkov konfliktov a protestov a sledovali sme výrazy, ktoré sa spájali s útočníkmi v prípadoch z Nového Boru a Rumburku. Zaujímalo nás, či bola ich príslušnost' $\mathrm{k}$ rómskej menšine zdôrazňovaná alebo boli prezentovaní ako individuality a samostatní aktéri a či konanie alebo vyjadrenia jednotlivcov boli spájané s menšinou ako celkom. V tret’om kroku sme venovali pozornost' prítomnosti dichotómneho delenia spoločnosti. Prezentovaný vzt'ah medzi majoritou a minoritou sme sledovali prostredníctvom pomenovaní a prívlastkov, kedy sme analyzovali jednotlivé výrazy, ktoré sa s týmito skupinami spájali, a prostredníctvom výberu a umiestnenia citácií, kedy sme skúmali, aký priestor a významnost’ boli prisudzované jednotlivým aktérom.

\section{Kontext skúmaného spravodajstva}

Sledované udalosti sa počas mesačného obdobia celkovo objavili v troch denníkoch v 74 spravodajských príspevkoch, pričom najväčšiu mediálnu pozornost’ získali protesty a niečo nižšiu pozornost' incidenty v Novom Bore a Rumburku. V priebehu analyzovaného mesiaca možno pritom z hl'adiska intenzity informovania o udalostiach $\mathrm{v}$ denníkoch napriek krátkemu obdobiu identifikovat' tri hlavné fázy. Prvá fáza trvala od informovania o útoku v Novom Bore (8. augusta) do incidentu v Rumburku (22. augusta). Denníky Blesk a MF Dnes sa spočiatku o incident takmer vôbec nezaujímali, uverejnili len krátke správy na okraji alebo spodnej časti novín. Na rozdiel od Blesku však MF Dnes informovala aj o tlačovej konferencii usporiadanej Rómami z Nového Boru a o proteste proti kriminalite z 15. augusta 2011. Denník MF Dnes začal ku koncu prvej fázy písat’ o téme v kontexte sociálneho napätia a ako jediný označil útok za rasovo motivovaný. Právo venovalo téme najviac priestoru od prvého útoku, intenzívne informovalo o okolnostiach, priebehu vyšetrovania a tlačovej konferencie Rómov.

Druhá fáza, kedy sa zmenil spôsob písania a intenzita informovania, začala 22. augusta, kedy noviny po prvýkrát priniesli informácie o incidente v Rumburku. Po udalosti sa začali všetky denníky zameriavat' na údajné zvyšujúce sa napätie na severe Českej republiky, obavy obyvatel'ov a politikov z rastúcej kriminality a na protesty, ku ktorým toto napätie viedlo. Násilné udalosti boli spočiatku prezentované prevažne ako prvotný impulz na spustenie protestov, v neskorších správach boli označované ako posledná kvapka v dlhodobo napätej situácii. V tomto období udalosti získavali priestor na titulných stranách alebo inom viditel’nom mieste $\mathrm{v}$ podobe rozšírených správ. Tretia fáza informovania začala koncom augusta, kedy médiá strácali o tému záujem a prevažovali krátke správy umiestnené na menej viditel'ných miestach, ktoré informovali o d’alších plánovaných protestoch. Záujem médií oživili až nasledujúce protirómske demonštrácie v septembri 2011 vo Varnsdorfe.

Sledované incidenty boli vo všetkých troch denníkoch rámcované ako vyvrcholenie dlhodobo sa stupňujúceho napätia medzi majoritou a minoritou a problémov s „rómskou“ kriminalitou. Denníky 
zároveň často opomínali nízky vek niektorých útočníkov, ktorí boli v danom čase maloletí a zlú sociálnu situáciu, pričom napätie zvykli predostierat' ako fakt bez dostatočnej argumentácie. V prípade, že sa denníky zaoberali inými prípadmi násilných udalostí medzi väčšinou a menšinou, prezentovali ich ako systematické prelievanie napätia z dôvodu rómskej „,neprispôsobivosti“. MF Dnes v správe s titulkom Napètí po útocích Romi se preléva z. mèsta do mèsta. Hrozí „Londýn“? (24. augusta 2011) v úvodnej časti správy spomínala d’alšie incidenty v oblasti v rozpätí asi jedného roka pred augustom 2011 a pripojila k správe mapu, na ktorej boli v podobe ohnísk znázornené „ghettá neprispôsobivých“a a šípky, ktoré znázorňovali smer st’ahovania Rómov na sever.

Sociálny kontext sa v denníkoch začal objavovat' až po útoku v Rumburku a okrem zmienok o nezamestnanosti, zdôrazňoval vysokú kriminalitu prameniacu zo zlej sociálnej situácie a napätia medzi väčšinou a Rómami. Denníky informovali o skupine tzv. neprispôsobivých, ktorí boli do oblastí, v ktorých došlo $\mathrm{k}$ incidentom a nepokojom, st’ahovaní realitnými kanceláriami. Táto teória nebola $\mathrm{v}$ správach podporovaná oficiálnymi vyjadreniami autorít, ale len konštatovaniami autorov správ a obyvatel'ov. Redaktor Práva napríklad zhodnotil, že „, r regionu v posledních měsících roste napětí mezi starousedlíky a Romy, které tam sestěhovaly realitní kanceláře spekulující s byty“ (Právo, 5. septembra 2011). Denník Blesk zase parafrázoval názory miestnych obyvatel'ov, ked’ uviedol, že „místní tvrdí, že realitky kupují ve středních Čechách byty i s nepřizpůsobivými, které pak odstěhují na sever a opravené byty prodaji“‘ (Blesk, 27. augusta 2011).

Kontext incidentov bol v niektorých prípadoch pozmenený aj zámernou korekciou citácií. Správa MF Dnes (18. augusta 2011) s titulkom Tak jsme to tém bílejm blavám nandali, v ktorej redaktorka čerpala informácie zo záznamu bezpečnostných kamier poskytnutého barmankou, bola uverejnená v tlačenej aj internetovej verzii v podobách, ktoré sa líšili v niekol'kých podstatných detailoch. Kým v tlačenej verzii je komentár barmanky označený ako „doplňujúce svedectvo“, v elektronickej verzii záznam len „okomentovala“. Barmanka je zároveň zdrojom informácie z titulku - v tlačenej verzii čast' správy znie ,'Tak jsme to těm bílejm hlavám nandali', říká na záznamu jeden z útočníkư“', zatial’ čo v elektronickej verzii sa píše ,'Tak jsme to těm bílejm hlavám nandali', řekl pak podle barmanky jeden z útočníkư“ (MF Dnes, 18. augusta 2011). Záznam z bezpečnostnej kamery bol navyše snímaný bez zvuku, čo nie je explicitne spomenuté ani v jednej verzii. Tlačená verzia správy tak implikuje rasový motív útočníkov.

\section{Zdôrazňovanie etnicity a generalizácia „,rómskej“ kriminality}

Denníky pri informovaní o útokoch zdôrazňovali príslušnost' páchatel’ov $\mathrm{k}$ rómskej menšine a zovšeobecňovali dané prípady ako pokračujúcu kriminalitu Rómov, pričom naznačovali súvislost' medzi zhoršujúcou sa bezpečnostnou situáciou a agresivitou rómskej menšiny. Ako ukazuje tabul'ka 1, opisy páchatel’ov z útoku v Novom Bore sa v priebehu niekol'kých dní zmenili z mladíkov a agresorov na dalš ze skupiny útočnikư z. nepriapuisobivých rodin a partu pèti Romů s mačetami. Po útoku v Rumburku už denníky písali o skupinke romských útočnikiu alebo o rozzurených Romech. V prípade Nového Boru tento obrat nastal v čase, ked' vyšla najavo príslušnost' útočníkov k rómskej menšine. Prestalo sa o nich písat' ako o násilníkoch alebo l'ud’och a boli kolektívne označení ako Rómovia. 
Tabul'ka č. 1 Opisy a charakteristiky útočníkov v incidentoch v Novom Bore a Rumburku

\begin{tabular}{l|l|l}
\hline Dátum & Denník & Použitý opis \\
\hline $08 / 08 / 2011$ & MF Dnes & několik lidí s mačetami \\
\hline $09 / 08 / 2011$ & Blesk & mladík, aktér, agresor \\
\hline $11 / 08 / 2011$ & Právo & násilníci s mačetami \\
\hline $13 / 08 / 2011$ & Blesk & další ze skupiny útočníků z nepřizpůsobivých rodin \\
\hline $13 / 08 / 2011$ & MF Dnes & parta pěti Romů s mačetami \\
\hline $16 / 08 / 2011$ & Právo & pětičlenná skupina místních Romů \\
\hline $18 / 08 / 2011$ & MF Dnes & trestní komando, útočníci romského původu \\
\hline $23 / 08 / 2011$ & Právo & skupina Romů \\
\hline $23 / 08 / 2011$ & MF Dnes & skupinka romských útočníků \\
\hline $24 / 08 / 2011$ & MF Dnes & hlučné a agresivní skupinky mladých Romů \\
\hline $26 / 08 / 2011$ & Blesk & $\begin{array}{l}\text { rozzuření Romové, agresivní Romové, sociálně slabí a nepřizpůsobiví } \\
\text { lidé }\end{array}$ \\
\hline
\end{tabular}

Zdroj: autorky

Mladíci, ktorí sa zúčastnili bitky v Rumburku, boli od začiatku prezentovaní ako Rómovia. Ked’že ale polícia oznámila, že bude prešetrovat' tento incident ako rasovo motivovaný (hoci napokon len $\mathrm{v}$ jednom prípade bol obžalovaný súdený za obvinenia s rasovým podtextom), v tomto prípade takéto formulácie boli odôvodnené. Napriek tomu možno v jednotlivých denníkoch vidiet’ v informovaní o útoku významové rozdiely. Tabul'ka 2 ukazuje, aké titulky sa objavili v denníkoch bezprostredne po útoku.

Denník Právo ako jediný v titulku neuviedol, že sa incidentu v Rumburku zúčastnili Rómovia a taktiež ako jediný naznačil, že rasový podtext bol len jedným z motívov, ktoré v tom čase polícia zvažovala. MF Dnes a Blesk v titulkoch etnicitu jednej skupiny účastníkov uviedli, a to aj napriek tomu, že sa v správe nevenovali možnosti rasového motívu. Denníky tiež poukazovali na podobnost' bitky s útokom v Novom Bore. Denník MF Dnes v správe Útok. Romũ: dvacet proti šesti označil incident v Novom Bore za rasovo motivovaný, hoci prípad tak posudzovaný nebol a ani obžalovaní neboli súdení za prečin s rasovým podtextom. Rómovia boli pritom v danej správe spomínaní pät'krát, a to vždy v spojení s násilím alebo zločinom.

Tabul'ka č. 2. Titulky správ o bitke v Rumburku, ktorá sa odohrala 21. augusta 2011 večer

\begin{tabular}{l|l|l}
\hline Dátum & Denník & Titulok \\
\hline \multirow{3}{*}{$22 / 08 / 2011$} & Právo & Bitka v Rumburku mohla mít rasový motiv \\
\cline { 2 - 3 } & Blesk & $\begin{array}{l}\text { Férovka? 18 Romů ztlouklo šestici mladíků! } \\
\text { Romská přesila tvrdě pomlátila šest mladíků }\end{array}$ \\
\cline { 2 - 3 } & \multirow{2}{*}{ MF Dnes } & $\begin{array}{l}\text { Útok Romů: dvacet proti šesti } \\
\text { Útok Romů byl rasistický. Lidé na severu si kupují zbraně a psy }\end{array}$ \\
\hline
\end{tabular}

Zdroj: autorky 
Napriek tomu, že presné okolnosti incidentu v danom štádiu ešte neboli známe, v správach, ktoré denníky vydali bezprostredne po bitke, boli Rómovia označovaní ako útočníci a agresori a bola zdôrazňovaná ich rozzúrenost' a agresivita, pričom druhá skupina mladíkov bola opisovaná v úlohe pasívnych obetí, ktorí sa pred útočníkmi bránili.

Pořádnou řezbou skončilo setkání šesti mladíků s osmnáctičlennou skupinou Romů na okraji Rumburku. Oba tábory se do sebe pustily v neděli nad ránem. Mladíci se před Romy vyzbrojenými dlažebnými kostkami a teleskopickými obušky pokusili ukrýt $\mathrm{v}$ jednom z domů, útočníci ale dveře vyrazili. Jeden z napadených leží v nemocnici.

(Blesk, 22. augusta 2011, zdôraznenie doplnené)

Romové v Rumburku na Děčínsku v noci zbili mladíky vracející se z narozenin. Útočníci byli ve velké přesile a použili kovový obušek. Jedna $\mathbf{z}$ obětí skončila $\mathrm{v}$ nemocnici s rukou zlomenou na čtyřech místech.

(MF Dnes, 22. augusta 2011, zdôraznenie čiernou doplnené, zdôraznenie červenou prevzaté z originálu 5 )

V oboch úryvkoch možno sledovat' jasnú identifikáciu prislúchajúcich rolí jednotlivých aktérov. Jedna skupina konfliktu bola označená ako Rómovia a útočníci a druhá skupina ako mladíci a obete. Denník Blesk aj napriek tomu, že píše o tom, že obe skupiny sa stretli a „do seba pustili“ (22. augusta), napadnutí mladíci sa skryli pred útoćiacimi Rómami. V úryvkoch je prítomný aj element dôrazu na nezvyčajné použitie sily - Rómovia vyzbrojení dlažobnými kockami a teleskopickými obuškami, vo vel'kej presile vyrazili dvere. Podobne aj pri útoku v Novom Bore bola udalost' opisovaná ako krvavá a brutálna a boli podrobne opisované rôzne druhy údajne použitých zbraní. V tabul'ke 3 sú uvedené príklady zdôrazňovania príslušnosti zúčastnených aktérov k rómskej menšine, ktoré priniesli denníky v titulkoch

Tabul'ka č. 3. Zdôrazňovanie príslušnosti zúčastnených aktérov $\mathrm{k}$ rómskej menšine $\mathrm{v}$ titulkoch

\begin{tabular}{l|l|l}
\hline Dátum & Denník & Použitý opis \\
\hline 13/08/2011 & Právo & Romové: Za mačetový útok v Novém Boru může servírka \\
\hline 13/08/2011 & MF Dnes & Romové o masakru: Byla to jen běžná hospodská rvačka \\
\hline 25/08/2011 & Blesk & Starostka Šluknova: Když nedostanou Romové dávky, jdou krást \\
\hline 26/08/2011 & MF Dnes & Trestejte př́sněji, ř́ká Rom \\
\hline 30/08/2011 & Právo & Romové: Dřív zašli na kafe, ted’ nás nenávidí \\
\hline 31/08/2011 & Právo & Starosta Boru: stát často Romům práci bere \\
\hline
\end{tabular}

Zdroj: autorky

5 MF Dnes často $\mathrm{v}$ perexoch zozbieraných článkov zvýraznila niekol’ko slov, najčastejšie červenou farbou. Ďalšie zvýraznenia boli „rasově motivovaného útoku“, “rostlo etnické napětí kvůli kriminalitě Romü“, „Romští starousedlíci“, „pro sociálně slabé na Šluknovsku“ a „,kamerový záznam“. 
Okrem zdôrazňovania etnicity útočníkov bolo správanie jednotlivcov prenášané na celú menšinu a ich výroky alebo charakteristiky aplikované na komunitu ako celok. Už pri prvotnom informovaní o bitke $\mathrm{v}$ Rumburku denníky naznačili súvislost' medzi zhoršujúcou sa bezpečnostnou situáciou a (vnímanou) agresivitou Rómov. MF Dnes deň po útoku informovala, že „ve Varnsdorfu se minulý týden kvưli neustále se zhoršující bezpečnostní situaci sešlo několik desítek lidí, kteří si stěžovali, že se kvưli agresivitě zdejších Romů bojí chodit ven“ (MF Dnes, 22. augusta 2011). Rasový motív bol v denníku zopakovaný aj v správe z nasledujúceho dňa s titulkom Útok Romu byl rasistický. Lidé na severu si kupuji zbraně a psy (MF Dnes, 23. augusta 2011), ktorý naznačoval nebezpečenstvo hroziace l'ud’om zo strany Rómov. Účastníci sledovaných incidentov pritom nie sú zobrazovaní ako jednotlivci, ale ako členovia skupiny, konkrétne rómskej menšiny.

Vo viacerých prípadoch titulky správ minimálne čiastočne nekorešpondovali s obsahom textu. Hoci je to bežná prax novinárov - vytiahnut' a zvýraznit' niektorý aspekt správy, aby príspevok pôsobil zaujímavo a upútal pozornost' čitatel'ov, titulok môže pôsobit' zavádzajúco. Denník Blesk (25. augusta 2011) uverejnil správu Starostka Šluknova: Když nedostanou Romové dávky, jdou krást, v ktorom denník priniesol vyjadrenia starostky o príčinách napätej situácie v obci Šluknov. Starostka za dôvod označila príliv sociálne slabých a neprispôsobivých občanov z iných častí Českej republiky, dvakrát však zdôraznila, že problém nie je len s prist’ahovalcami rómskeho pôvodu a že v meste majú s miestnou rómskou komunitou dlhodobo dobré vzt’ahy. Nepozmenený citát z rozhovoru znie: „Když lidé nedostanou peníze v dávkách, jdou krást.“ (Blesk, 25. augusta 2011). Redaktori správy v titulku následne vymenili „’udi““ za „Rómov“. Okrem toho, že výrok starostky je významovo posunutý, dochádza tu aj ku generalizácii Rómov ako zlodejov a l’udí zo sociálne slabších pomerov.

Generalizáciu ilustruje tiež správa denníka Blesk (1. septembra 2011) s titulkom Jak se krade na Šluknovsku. Test Blesku - Odloženou peněženku sebrali za 8 minut, ktorá sa síce priamo netýkala útokov, ani protestov, ale vznikla ako priama reakcia na ne. Predmetom správy bol „experiment“ denníka, v rámci ktorého redaktori na verejné miesta vo Varnsdorfe a Rumburku umiestnili rôzne predmety (peňaženka, mobil, taška, bicykel) a čakali, kto ich ukradne, pričom každého odfotografovali. Redaktori si dali za ciel’ overit’ tvrdenie „šluknovských starousedlíkư“, že zvýšenie napätia v oblasti má na svedomí rast kriminality, za ktorú môžu Rómovia. Pri opisoch ludí, ktorí si odniesli predmety, etnickú príslušnost' zvýraznili len u Róma, ktorý si vzal tašku a ktorého redaktor opísal ako rómskeho mladíka. Pri opisoch ostatných (nerómskych) l'udí, ktorí predmety vzali, nebola spomenutá farba pleti ani vlasov, len odhadovaný vek. Bicykel bol zároveň zanechaný v blízkosti hrajúcich sa rómskych detí a redaktor komentujúco vyjadril prekvapenie, že i ked' sa na bicykel prišlo pozriet' niekol'ko skupiniek detí a mladistvých, ani po niekol'kých hodinách si ho nikto neodniesol. Týmito a podobnými technikami vzniká dojem, že dlhodobá nezamestnanost’ a kriminalita sú rómske fenomény, aplikovatel'né na celú menšinu.

Vyjadrenia jednotlivca denníky často prezentovali ako stanovisko Rómov, teda celej menšiny. V správe Romové: Za mačetový útok v Novém Boru může servírka (Právo, 13. augusta 2011) stanovisko jedného zo zúčastnených na tlačovej konferencii, ktorú usporiadala Česko-romská společnost v Novom Bore pozmenili do podoby, že ide o kolektívne rómske presvedčenie. Ten prehlásil, že 99 percent viny nesie servírka, ktorá nemala chlapcov do podniku vôbec púšt’at', čo denník prezentoval nielen ako oficiálne stanovisko usporiadatel’ov, ale aj všetkých Rómov. 
Rómska menšina je spomínaná v spojitosti so zločinom a násilím aj v správach, ktoré sa priamo netýkajú incidentov zo 7. a 21. augusta. Ako ukazujú nasledujúce ukážky, v mnohých správach boli Rómovia zobrazovaní ako zdroj kriminality a násilia, prípadne redaktori priamo písali o „rómskej kriminalite“ alebo podporovali stereotyp, že každého Róma je potrebné preventívne podozrievat' z krádeže.

Nejprve drobné krádeže, pak přepadení a nakonec brutální útoky s těžce zraněnými. Takto eskaluje napětí mezi Romy a dalšími obyvateli v městech Šluknovského výběžku během posledního půl roku.

(Blesk, 25. augusta 2011, zdôraznenie doplnené)

Bouřlivé bylo také setkání starosty Varnsdorfu s občany, kteří jsou nespokojeni s opatřeními radnice, jež mají zamezit romské kriminalitě.

(Blesk, 29. augusta 2011, zdôraznenie doplnené)

Desítky policistů dorazily do měst ve Šluknovském výběžku, kde rostlo etnické napětí kvůli kriminalitě Romů. Starousedlíci si posily pochvalují.

(MF Dnes, 25. augusta 2011, zdôraznenie pridané)

Asi dvacetiletý Rom kráčel v úterý odpoledne centrem Šluknova a nesl si stolek. Najednou u něj zastal hlídkový vưz a policisté začali hned ověřovat původ nábytku. „Když bude někde chybět stolek, víme, kam máme jít,“ varovali policisté Roma. Tato scénka se mohla na Šluknově odehrát jen díky policejním posilám, které sem poslalo policejní prezídium.

(MF Dnes, 25. augusta 2011, zdôraznenie doplnené)

Hoci sa niektoré správy primárne zaoberali zlou sociálnou situáciou, zároveň v nich bola zdôrazňovaná rómska etnicita $\mathrm{v}$ spojení $\mathrm{s}$ kriminalitou a násilím. V článku s názvom Romové z. ubytovny. Bydlí jich tady 167, do práce chodí trí, autor konštatoval, že ,právě děti z ubytoven jsou dnes největším problémem Šluknovska. Ti menší kradou, starší se perou“ (MF Dnes, 29. augusta 2011). Ďalšia správa Divoký sever: Napètí po útoku v Novém Boru silí (MF Dnes, 19. augusta 2011) sa zaoberala rastom napätia z dôvodu rastúcej kriminality spôsobenej zlou sociálnou situáciou. Redaktori citovali viacero autorít - riaditel'a pre sociálne začleňovanie, sociológa aj starostu Varnsdorfu. Hoci ani jeden z nich nespomenul Rómov, len nezamestnaných, sociálne slabších, deti z problémových rodín a podobne, redaktor budoval spojitost' medzi násilím a kriminalitou a Rómami v oblasti, spomínal incidenty, pri ktorých útočníkmi boli Rómovia, a neuvádzal žiadne, pri ktorých by nimi neboli. Celkovo boli Rómovia zobrazovaní v spojení s kriminalitou alebo násilím vo väčšine správ, ak nie explicitne, tak minimálne implicitne.

\section{Dichotómne delenie spoločnosti}

Okrem priameho alebo nepriameho spájania Rómov s kriminálnou činnost’ou bolo v denníkoch prítomné výrazné vymedzovanie vzt'ahu medzi majoritnou spoločnost'ou a rómskou minoritou. 
Rómom navyše poskytovali médiá v porovnaní s väčšinovým obyvatel'stvom menší priestor na názor a ich vyjadrenia boli kolektivizované a často anonymizované, kedy nehovorila konkrétna osoba označená menom a priezviskom, ale Róm bez bližšej identifikácie. Delenie spoločnosti na dve skupiny tak bolo viditel’né aj na spôsobe citovania a označovania zdrojov informácí́.

Tabul'ka č. 4. Výrazy využívané na pomenovanie väčšinového obyvatel’stva a rómskej menšiny

\begin{tabular}{l|l|l|l}
\hline Dátum & Denník & Väčšinové obyvatel’stvo & Rómska menšina \\
\hline $12 / 08 / 2011$ & Blesk & lidé z Nového Boru & skupina Romů \\
\hline $13 / 08 / 2011$ & Právo & & skupiny místních Romů \\
\hline $16 / 08 / 2011$ & MF Dnes & Lidé & Romové, místní Romové \\
\hline $22 / 08 / 2011$ & Blesk & & $\begin{array}{l}\text { sociálně slabí a nepřizpůsobiví lidé, } \\
\text { Romové }\end{array}$ \\
\hline $22 / 08 / 2011$ & Právo & místní starousedlíci & \\
\hline $23 / 08 / 2011$ & MF Dnes & Místní & Romové \\
\hline $24 / 08 / 2011$ & MF Dnes & „bílí, starousedlíci & $\begin{array}{l}\text { problematičtí přistěhovalci, } \\
\text { nepřizpůsobiví lidé, Romové, skupinky } \\
\text { mladých Romů }\end{array}$ \\
\hline $24 / 08 / 2011$ & Právo & Starousedlíci & nepřizpůsobiví, Romové \\
\hline $25 / 08 / 2011$ & MF Dnes & Starousedlíci & romští starousedlíci \\
\hline $25 / 08 / 2011$ & Blesk & bílé mladíky, starousedlíci & $\begin{array}{l}\text { nepřizpůsobiví lidé, Romové, romská } \\
\text { menšina }\end{array}$ \\
\hline $27 / 08 / 2011$ & Blesk & Starousedlíci & Romové, nepřizpůsobiví \\
\hline $29 / 08 / 2011$ & Právo & stovky rozhořčených obyvatel & Romové \\
\hline $30 / 08 / 2011$ & MF Dnes & místní, lidé z majority & sociálně slabé, Romové \\
\hline
\end{tabular}

Zdroj: autorky

Systematický „othering“, vyčleňovanie menšiny do kategórie „tí druhí“, sa dial na dvoch úrovniach. $\mathrm{Na}$ jednej bolo v denníkoch toto delenie prítomné vo forme kolektívnych kategórií miestni a Rómovia, na druhej dochádzalo k transformácii kategórií do označení starousadlíci a neprispôsobiví. Príklady výrazov, ktoré denníky využívali na skupinové pomenovania majority a minority pri informovaní o protestoch a situácií v regióne, sú zhrnuté v tabul'ke 4.

Pojem neprispôsobiví mal síce pôsobit' etnicky nezat'ažene, no v médiách (ale tiež u politikov a aktérov krajnej pravice) sa synonymicky zamieňal s Rómami a prist’ahovalcami. $\mathrm{Na}$ jednej strane tak pojem mal byt' hodnotovo neutrálny a označovat' kategóriu l’udí bez ohl’adu na ich etnickú, národnostnú alebo inú príslušnost', čím sa mal vyhnút' rasistickému tónu, no pri spôsobe jeho používania jasne označoval presne vymedzenú skupinu l’udí na základe ich farby pleti. Podobne ako pojem neprispôsobiví bol formovaný aj pojem starousadlici, ktorý bol významovo spojený s väčšinovými miestnymi obyvatel’mi. Starousadlíkmi pritom v obciach boli aj niektorí Rómovia, ktorí na území žili rovnako dlho ako takto označované väčšinové obyvatel’stvo. Nasledujúce ukážky ukazujú dichotómne delenie spoločnosti a zároveň aj zdôrazňovanie existencie napätia medzi dvomi skupinami, ktoré toto delenie ešte zvýrazňovalo. 
V regionu v posledních měsících roste napětí mezi starousedlíky a Romy.

(Právo, 30. augusta 2011, zdôraznenie doplnené)

Napětí mezi starousedlíky a Romy se stupňuje poslední dva roky.

(Blesk, 27. augusta 2011, zdôraznenie doplnené)

Kvůli rostoucímu napětí mezi nedávno přistěhovalými Romy a starousedlíky se starostové na severu Čech obávají vypuknutí vážnějších nepokojů.

(MF Dnes, 24. augusta 2011, zdôraznenie doplnené)

Na významové rozdiely medzi výrazmi neprispôsobiví a Rómovia poukazovali najmä citované autority ako polícia, starostovia miest či sociálni pracovníci. A hoci redaktori v niektorých prípadoch v správach uvádzali, že pod neprispôsobivými majú na mysli novoprist’ahovaných nezamestnaných, z ktorých väčšina je rómskeho pôvodu a že s rómskymi starousadlíkmi (MF Dnes, 25. augusta 2011) nie sú nevyhnutne problémy, napriek tomu vo zvyšných častiach textu používali výrazy Rómovia a neprispôsobiví ako synonymá.

Napjatou situaci, kterou ještě vyhrotily nedávné rasistické útoky Romů v Novém Boru a Rumburku, se snaží uklidnit policejní posily ze zásahových jednotek. Podle místních za vše může masivní př́iliv nepřizpůsobivých lidí z jiných oblastí Čech.

(Blesk, 25. augusta 2011, zdôraznenie doplnené)

Situace ve Šluknovském výběžku je kvưli zvyšující se kriminalitě a př́livu nepřizpůsobivých zjitř̌ená delší dobu. ... Napětí mezi starousedlíky a Romy ve Šluknovském výběžku se stupňuje.

(Právo, 24. augusta 2011, zdôraznenie doplnené)

Zavřená okna, ticho, klid. Život v ubytovnách pro sociálně slabé na Šluknovsku se minulý týden výrazně změnil. Romové zůstávají doma, bojí se odplaty od extremistů i místních, kteří je viní z nárůstu kriminality a násilných útoků.

(MF Dnes, 29. augusta 2011, zdôraznenie doplnené)

Tomuto významovému prekrývaniu sa vyhýbalo najmä Právo, v ktorom spomedzi ostatných sledovaných denníkov najčastejšie neboli neprispôsobiví zamieňaní za Rómov. V ukážke sa nachádza čast' správy, v ktorej nebola zdôraznená etnicita starousadlíkov, prist’ahovalcov ani sociálne slabých, hoci možno jasne identifikovat' dve oddelené skupiny. Takéto vyjadrenia sa však v skúmanej vzorke vyskytovali sporadicky.

Ve šluknovském výběžku stále roste sociální napětí. Do oblasti se přistěhovala řada sociálně slabých lidí, které místní starousedlíci viní z nárůstu kriminality. V některých obcích se zvýšil počet krádeží až o 200 procent. 
Výnimku tvorilo niekol'ko správ, ktoré boli obsahovo zamerané na obavy „slušných Rómov“ (Blesk 29/08/2011, 30/08/2011, MF Dnes 29/08/2011, Právo 30/08/2011) z extrémizmu a z toho, že budú spájaní s „problémovými Rómami“. I ked’ tu boli do protikladu stavaní Rómoviastarousadlíci a Rómovia-prist'ahovalci, absentoval názor, že k problémovým obyvatel'om mohli patrit' napríklad i príslušníci majority. Tento pohl’ad na problematiku sa vyskytoval len v malej časti skúmaných správ.

Z pohladu frekvencie citovania boli príslušníci rómskej menšiny podreprezentovaní a v porovnaní s väčšinovým obyvatel’stvom im bol poskytnutý menší priestor na vyjadrenia. Navyše denníky mali tendenciu v niektorých prípadoch vyberat' citované osoby spôsobom, ktorý podporoval argument o kriminalite a problémovosti rómskej menšiny. Väčšina citácií $\mathrm{v}$ skúmanej vzorke pochádzala od polície, starostov, miestnych (väčšinových) obyvatel’ov alebo organizátorov protestov (tabul'ka 5). Ak mali Rómovia šancu na vyjadrenie, väčšinou im poskytli priestor až na konci správy a ich názory boli kolektivizované a prenášané na menšinu ako celok. V správe Policejní posily na Šluknovsku. Nestal se ani jeden trestni čn (MF Dnes, 25. augusta 2011) podstatnú čast' textu tvorili vyjadrenia „bielych starousadlíkov“, ktorí vyjadrovali spokojnost’ s policajnými posilami a až na konci citovali „starší ženu ze Šluknova“ rómskeho pôvodu, ktorá tvrdila, že „nových Romáků už jsem se začínala bát“. Navyše, hoci podtitulok správy znel Hlídky vítaji i romští starousedlíci, v príspevku okrem spomínanej ženy neposkytol denník Rómom žiaden priestor. Podobne v správe Policisté prüjeli zahnat strach (Blesk, 25. augusta 2011) dali priestor najskôr starostke, hovorkyni polície a majitel'ovi bytového domu a až na konci správy mužovi, ktorý je opísaný ako Róm (60), nemá meno a je zdôraznené, že je na Šluknovsku len niekol'ko mesiacov.

Tabul'ka č. 5. Zdroje citácií vo vybraných správach

\begin{tabular}{l|l|l|l}
\hline Dátum & Denník & Väčšinové obyvatel'stvo & Rómska menšina \\
\hline $11 / 08 / 2011$ & Právo & $\begin{array}{l}\text { starosta Nového Boru Jaromír Dvořák, } \\
\text { mluvčí Českolipské policie Ivana Baláková, } \\
\text { kamarád a matka jednoho ze zraněných, } \\
\text { nejmenovaní uspořadatelé plánovaného } \\
\text { protestu proti kriminalitě }\end{array}$ & $\begin{array}{l}\text { předseda Česko-romské } \\
\text { společnosti v Novem Boru Štefan } \\
\text { Gorol }\end{array}$ \\
\hline $18 / 08 / 2011$ & MF & $\begin{array}{l}\text { nejmenovaná zaměstnankyně baru, [kde } \\
\text { došlo k útoku], nejmenovaný majitel baru }\end{array}$ & $\begin{array}{l}\text { Tancoš, rodiče obviněných - } \\
\text { matka a otec Jakuba Žigu, matka } \\
\text { predseda Romské hospodářské }\end{array}$ \\
\hline Antonína Sina
\end{tabular}


Alena Kluknavská, Lenka Zagibová: Neprispôsobiví Rómovia a slušná väčšina?

\begin{tabular}{|c|c|c|c|}
\hline $25 / 08 / 2011$ & Blesk & $\begin{array}{l}\text { starostka Šluknova Eva Džumanová, } \\
\text { mluvčí děčínské policie Petra Trypesová }\end{array}$ & \\
\hline $26 / 08 / 2011$ & $\begin{array}{l}\text { MF } \\
\text { Dnes }\end{array}$ & & $\begin{array}{l}\text { sociálny pracovník - Rom, který si } \\
\text { neželal být jmenovaný }\end{array}$ \\
\hline $26 / 08 / 2011$ & Právo & $\begin{array}{l}\text { policie, místní občané [vyjadrujúci } \\
\text { spokojnost’s prácou polície] }\end{array}$ & $\begin{array}{l}\text { Rom (60), který se do Šluknova } \\
\text { pristehoval prred devíti měsíci }\end{array}$ \\
\hline $27 / 08 / 2011$ & Blesk & $\begin{array}{l}\text { představitel občanské iniciativy Občanský } \\
\text { odpor Rumburk Josef Mašín }\end{array}$ & \\
\hline $29 / 08 / 2011$ & Blesk & starosta Varnsdorfu Martin Louka & starousedlý Rom Milan \\
\hline $29 / 08 / 2011$ & $\begin{array}{l}\text { MF } \\
\text { Dnes }\end{array}$ & $\begin{array}{l}\text { starosta Varnsdorfu Martin Louka, správce } \\
\text { ubytovny Karel Jiřrišta, Michal [účastník } \\
\text { roztržky z Rumburku], policejní mluvčí Jan } \\
\text { Melša }\end{array}$ & $\begin{array}{l}\text { Romové z ubytovny }- \text { muž } \\
\text { v nátělníku, drobounká Romka, } \\
\text { pan Zdeněk }\end{array}$ \\
\hline
\end{tabular}

Zdroj: autorky

Najviac priestoru získala menšina v denníkoch na konci augusta, kedy sa objavili správy, ktoré prezentovali Rómov ako obete (Právo, 30. augusta 2011) alebo vysvetlovali rozdiel medzi starousadlými a novoprist'ahovanými Rómami (Blesk, 29. a 30. augusta 2011). Jediným elitným rómskym zástupcom, ktorého denníky citovali, bol predseda Česko-rómskej spoločnosti v Novom Bore Štefan Gorol, ked’že občianske združenie zorganizovalo po útoku v Novom Bore k udalostiam tlačovú konferenciu. Denníky, s výnimkou Blesku, ktorý o udalosti neinformoval vôbec, pritom prezentovali jeho názory ako vyjadrenie povereného zástupcu rómskej menšiny a jeho hlas bol generalizovaný ako hlas všetkých Rómov.

Denníky citované osoby rómskeho pôvodu uvádzali ako anonymné individuality alebo kolektívneho aktéra (Rómovia, neprispôsobivî), prípadne citovali niekol'ko konkrétnych rómskych obyvatel’ov, tí však často vyjadrovali názor zhodný s názorom väčšiny. V správe, ktorá informovala o útoku v Novom Bore s titulkom Byl to likvidačni útok (MF Dnes, 18. augusta 2011), boli medzi citovanými barmanka, majitel herne a predseda Romské hospodářské rady v Novem Boru Miroslav Tancoš, ktorý nemal s útokom priamu súvislost’. Vyjadril sa, že „Romáci by měli projevit víc pokory. Za ten útok se omluvit a uhradit veškerou škodu za léčeni““. V správe sú tiež citovaní rodičia niektorých útočníkov. Zatial’ čo Tancoš v správe „míní osvíceně“, rodičia (rómskeho pôvodu) „prízvukujúu, jedna matka „naříká a dušuje se“ a „by odpřisáhla“, ked’ hovorí o synovi. Z celkového pohl’adu bola menšina v porovnaní s majoritou citovaná vel’mi málo a zároveň anonymizovane, čo často mohlo pôsobit' z pohl'adu čitatel’a podozrivo.

\section{Záver}

V druhej polovici roku 2011 sa v oblasti Šluknovska na severe Českej republiky zvýšilo napätie medzi väčšinovým obyvatel'stvom, obyvatel'mi sociálne vylúčených lokalít a Rómami, ktoré v niektorých mestách vyústilo do protestov a demonštrácií. Protirómska rétorika sa stala súčast'ou prejavov nielen krajne pravicových aktérov, ale tiež niektorých lokálnych politikov a miestnych obyvatel'ov. Podl'a Zprávy o stavu romské menšiny v ČR (2012) za rok 2011 k eskalácii napätia mali prispiet' jednak 
vysoká nezamestnanost' a socioekonomická situácia obyvatel'ov a zhoršenie bezpečnostnej situácie, kedy Polícia ČR zaznamenala nárast drobných krádeží a vlámaní, čo čast’ majority považovala za kriminalitu spôsobenú Rómami a jednak (vnímané) prist’ahovalectvo Rómov na sever z iných oblastí krajiny. Podl’a tejto správy (2012: 86) však „migrácia v regióne nebola v roku 2011 taká vysoká ako ju prezentovali médiá“".

V príspevku sme hl'adali odpoved' na otázku, akým spôsobom boli Rómovia zobrazovaní v troch najčítanejších českých denníkoch Blesk, MF Dnes a Právo v období jedného mesiaca po násilnom útoku na severe Českej republiky v auguste 2011. Zistili sme, že vybrané denníky v sledovanom období pri informovaní o útokoch zdôrazňovali príslušnost' páchatel’ov k rómskej menšine a zovšeobecňovali prípady ako pokračujúcu „rómsku“ kriminalitu, pričom naznačovali súvislost' medzi zhoršujúcou sa bezpečnostnou situáciou a vnímanou agresivitou rómskej menšiny. Sledované incidenty boli často prezentované jednak ako vyvrcholenie dlhodobo sa stupňujúceho napätia medzi dvomi homogénnymi skupinami - väčšinovými obyvatel’mi a rómskou menšinou a jednak ako dôsledok problémov s kriminalitou neprispôsobivých občanov, pod ktorých takmer exkluzívne zahŕňali príslušníkov rómskej menšiny. Takáto diskurzívna stratégia vytvára priestor na posun „tých druhých“, v tomto prípade Rómov, d’alej od „nás“ - väčšinovej spoločnosti. V spravodajskom diskurze tak možno pozorovat’ generalizáciu kriminálneho konania jednotlivcov Rómov na širšiu skupinu l’udí - rómsku menšinu. Referencie k rómskej etnicite v súvislosti s incidentmi a protestmi boli natol'ko zdôrazňované, že sa vytváral dojem spojitosti pojmov rómska a kriminalita.

Ked’že sa sledovaná vzorka správ priamo alebo nepriamo týkala násilných činov alebo protestov, nie je prekvapujúce, že Rómovia boli zobrazovaní v spojení s kriminalitou a násilím. V správach však bolo prítomné zdôrazňovanie etnickej príslušnosti aktérov, a to aj v prípadoch, kedy takéto označenie nebolo potrebné. Navyše, Rómovia ako skupina boli vinení nielen za konkrétne činy, ale aj za zvýšenú kriminalitu $\mathrm{v}$ regióne všeobecne, čím bolo konanie jednotlivcov generalizované na povahu celej menšiny. Denníky tak podporovali vnímanie kolektívnej viny, pri ktorej sú všetci Rómovia zarad'ovaní do jedného homogénneho celku. Podl'a Horváthovej (2002: 58) sa tento princíp na Rómov aplikuje „tým l’ahšie, že sa svojim vzhl’adom tak výrazne odlišujú od ostatnej populácie“. Negatívna skúsenost' s konkrétnou osobou sa potom jednoduchšie vztiahne na celú komunitu.

Okrem implikovanej spojitosti medzi Rómami a kriminalitou vybrané denníky vymedzovali hranice medzi majoritným obyvatel'stvom a rómskou menšinou, pričom delenie spoločnosti bolo budované na konflikte a napätí medzi týmito skupinami. Systematické vyčleňovanie Rómov do kategórie ,ini““ alebo „tí druhí“ bolo v denníkoch prítomné na úrovni explicitného označenia dvoch skupín (domáci a Rómovia) alebo na úrovni nepriamych kolektívnych kategórií (starousadlíci a neprispôsobivî́. Hoci druhá spomenutá úroveň mala pôsobit’ etnicky nezat’ažene, v médiách bola synonymicky zamieňaná s bielymi obyvatel'mi na jednej strane a Rómami na strane druhej. Podl’a Čadu (2012: 76) má takéto využívanie „kódových slov“ vyzerat’ rasovo netruálne a objektívne, ich obsah je však silne rasovo zafarbený. V rámci sledovaného diskurzu Rómovia tiež získavali v porovnaní s väčšinovými obyvatel'mi menší priestor na vyjadrenia a ich výpovede boli navyše často anonymizované. Spôsobom prezentovania tohto dichotómneho delenia tak bol vytváraný rámec, v ktorom má slušná majoritná čast’ obyvatel’stva problémy s neprispôsobivou rómskou menšinou. 
Homogenizácia útočníkov ako Rómov zapadá do kategorickej generalizácie, ktorá je často príznačná pre stereotypizáciu a kognitívne predsudky (van Dijk 1992). Čím väčšia kategória, tým rozsiahlejšia generalizácia a zároveň rozsiahlejšia stereotypizácia. Kategorizácia útočníkov zo skúmaných incidentov ako Rómov však neznamená len ich zaradenie do určitej etnickej schémy, ale ovplyvňuje tiež postoje a správanie l'udí voči rómskej menšine ako celku. Predstava útočníkov z daných prípadov môže vytvárat' diskurzívny rámec, kedy obvinení nepredstavujú miestnych agresorov, ale všetkých rómskych kriminálnikov. Toto dopĺňa tvrdenia Čadu (2012: 72-73, 77), podl’a ktorého verejnost' v Českej republike väčšinou považuje Rómov za neprispôsobivú čast' populácie, ktorá zneužíva sociálny systém a odmieta sa začlenit’ do pracovného trhu; preto si spôsobila svoju situáciu sama a nezaslúži si žiadnu externú pomoc.

Zistenia práce doplńajú doterajšie poznatky z oblasti výskumu zobrazovania menšín v spravodajstve masových médií a obohacujú skúmanie o empirické dáta z prípadu v Českej republike. Ďalší výskum by sa na základe predstavenej analýzy dal posunút' nielen smerom ku komparácii jednotlivých prípadov a väčšej generalizácii v rámci Českej republiky, prípadne $\mathrm{k}$ porovnaniu s prípadmi $\mathrm{v}$ iných krajinách, ale tiež ku komparácii jednotlivých úrovní, v rámci ktorých sa mediálne informácie dostávajú k čitatel’om, konkrétne celoštátnej a regionálnej, prípadne lokálnej úrovne (e.g. Chiricos, Escholz 2002).

Po skončení sledovaného obdobia sa médiá v súvislosti sútokmi najviac zamerali na pokračujúce demonštrácie a vel'kú čast' pozornosti venovali informovaniu o aktivite krajne pravicovej DSSS, ktorá rámcovala protesty ako odôvodnený hnev „obyčajných l’udí“, ktorých práva sú potláčané neprispôsobivou menšinou. Médiá $\mathrm{v}$ tomto prípade prispievali k priaznivej štruktúre diskurzívnych príležistostí pre krajne pravicových aktérov. Inými slovami, spravodajský diskurz $\mathrm{v}$ súvislosti s rómskou menšinou bol priaznivo naklonený diskurzu, ktorý vytvára krajná pravica stavajúca na animozitách voči rôznym nepriatel’om, v tomto prípade voči rómskej menšine, čo následne smeruje $\mathrm{k}$,potvrdeniu politického akceptovania anti-Cigánizmu“ v rámci verejného diskurzu (Albert 2012: 138). Ked’že však na úspešnost' politickej strany a hnutia v presadení agendy vplývajú d’alšie faktory spojené nielen s diskurzívnymi príležitost’ami, ale tiež napríklad s rezonanciou vytvorených rámcov u verejnosti (Snow, Benford 1988) alebo štruktúrou politických príležitostí (Kitschelt 1995), táto oblast' si vyžaduje d’alší výskum. V niektorých prípadoch, ako napríklad v Estónsku alebo Lotyššku, sa krajne pravicovým stranám nedarí aj z toho dôvodu, že radikálnu rétoriku extrémnej pravice prebrali do istej miery mainstreamové politické strany (Auers, Kasekamp 2009). Napriek tomu, popularita krajne pravicovej DSSS pomerne výrazne stúpla v regiónoch, kde boli ich obyvatelia naklonení prijímat' rasové vysvetlenia, ktoré im strana ponúkala (Čada 2012). S podobnou taktikou uspela na lokálnej úrovni do vel'kej miery aj L’udová strana Naše Slovensko (LSNS) v parlamentných vol'bách 2010 a 2012 (Kluknavská 2013) a jej líder Marian Kotleba v boji o predsednícke kreslo Vyššieho územného celku v Banskej Bystrici v regionálnych vol’bách 2013.

Súdny proces s obžalovanými z prípadu v Novom Bore vyvrcholil koncom júla 2013, kedy krajský súd v Liberci vyniesol rozsudok a odsúdil mužov na 3 až 16 rokov väzenia. Hoci médiá aj nad’alej informovali o etnicite útočníkov, obžalovaní neboli súdení za konanie s rasovým podtextom. 


\section{Bibliografia}

ABC ČR - Kancelář ověrování nákladu tisku (2011). Ověřovaná data - Deníky [online]. Dostupné z: http://www.abccr.cz/overovana-data/periodicky-tisk-1/?filterYear=2011\&filterMonth=8, [cit. 10. 6 . 2013].

Alba-Juez, L (2009). Perspectives on Discourse Analysis: Theory and Practise. Cambridge: Cambridge Scholars Publishing.

Albert, G. (2012). Anti-Gypsyism and the Extreme-Right in the Czech Republic. In: Stewart, M. (Ed.). The Gypsy Menace': Populism and the New Anti-Gypsy Politics, s. 137-166. C Hurst \& Co Publishers Ltd.

Auers, D. - Kasekamp, A. (2009). Explaining the Electoral Failure of Extreme-Right Parties in Estonia and Latvia. Journal of Contemporary European Studies, roč. 17, č. 2, s. 241-254. DOI: $10.1080 / 14782800903108718$

Badáňová, A (2010). Promèny mediální reprezentace Romů v českém tisku. Magisterská diplomová práce. Masarykova universita v Brně, Fakulta sociálních studií.

Bennett, L. W. - Entman, R. W. (2001). Mediated Politics: Communication in the future of democracy. Cambridge: Cambridge University Press Cambridge.

Blanche, T. M. - Durrheim, K. (1999, eds.). Research in practice: Applied methods for the social sciences. Cape Town: UCT Press.

Bobo, L. D (1997). Race, public opinion, and the social sphere. Public Opinion Quarterly, 1997, roč. 61, č. 1, s. 115.

Borgis. Právo: nezávislé noviny, roč. 21, č. 187-214. Praha: Borgis, a.s.

Čada, K. (2012). Social Exclusion of the Roma and Czech Society. In: Stewart, M. (Ed.). The Gypsy Menace': Populism and the New Anti-Gypsy Politics, s. 67-80. C Hurst \& Co Publishers Ltd.

Český statiscký úřad (2011). Konečné výsledky sč́tania ludu 2011 [online]. Dostupné z: http://vdb.czso.cz/sldbvo/\#!stranka=podle-

tematu\&tu $=30715 \& \mathrm{th}=\& \mathrm{v}=\& \mathrm{vo}=$ null $\& v$ seuzemi $=$ null\&void, [cit. 15. 4. 2013].

Centrum pro výzkum verejného mínení AV ČR (2013). Romové a soužití s nimi očima české verejnosti - duben 2013

[online]. Dostupné z: http://cvvm.soc.cas.cz/media/com_form2content/documents/c1/a7017/f3/ov130521.pdf, [cit. 22. 3. 2013].

Chiricos, T. - Eschholz, S. (2002). The Racial and Ethnic Typification of Crime and The Criminal Typification of Race and Ethnicity in Local Television News. Journal of Research in Crime and Delinquency, roč. 39, č. 4, s. 400-420. DOI: 10.1177/002242702237286

Dělnická strana Sociální Spravedlnosti (2011). DSSS se chystá do Novébo Boru [online]. Dostupné z: http://www.dsss.cz/dsss-se-chysta-do-noveho-boru, [cit. 10. 7. 2013].

Dělnická strana Sociální Spravedlnosti (2013a). DUCHCOV: Problém sociálně neprrappisobivých parazitù není tento rě̌z̧im schopen vyrěsit [online]. Dostupné z: http://www.dsss.cz/problem-socialne-neprizpusobivychobcanu-neni-tento-rezim-schopen-vyresit, [cit. 24. 8. 2013].

Dělnická strana Sociální Spravedlnosti (2013b). Strategie proti neprǐapisobivému stylu života [online]. Dostupné z: http://neprizpusobivi.dsss.cz/,[cit. 24. 8. 2013]

Gamson, W. A. (1992). Talking Politics. Cambridge: Press Syndicate of the University of Cambridge.

Hall, S. (1997). The Work of Representation. In Hall, S. (Ed.). Representation: Cultural Representations and Signifying 
Practices. London: Open University Press, s. 13-75.

Horváthová, J. (2002). Kapitoly z dẹjin Romü. Člověk v tísni: Lidové Noviny.

iDnes.cz. (2011). Horký pátek spustil zlobu a frustraci, Rumburští se nechali vést radikály [online]. Dostupné z: http://zpravy.idnes.cz/pochod-a-demonstrace-v-rumburku-dne-

/domaci.aspx?c=A110826_225545_domaci_ji, [cit. 16. 6. 2013].

Kim, S. (2012). Racism in the global era: Analysis of Korean media discourse around migrants, 1990-2009. Discourse \& Society, roč. 23, č. 6, s. 657-678.

Kitschelt, H. (1995). The Radical Right in Western Europe: A Comparative Analysis. Univesity of Michigan Press.

Kluknavská, A. (2013). Od Štúra k parazitom: Tematická adaptácia krajnej pravice v parlamentných vol'bách na Slovensku. Politologický časopis, roč. 2013, č. 3, s. 258-281.

Klváčová, P. - Bitrich, T. (2003). Jak se (ne)pišse o cizincich [online]. Dostupné z: http://aa.ecn.cz/img_upload/bacca6403f52f8f0f60667687afefbf5/Jak_se_ne_pise_o_cizincich_2003.p df, [cit. 16. 4. 2013].

Klvaňová, R. (2007). Uprchlíci v zabranič na stránkách českébo tisku [online]. Dostupné z: http://www.mkc.cz/uploaded/download/Cizinci_nasinci_a_media.pdf, [cit. 27. 3. 2013].

Koncept Rómskej integrácie pre 2010-2013, ČR (2009). Roma Integration Concept for 2010-2013, december $2009 \quad$ [online]. Dostupné z: http://ec.europa.eu/justice/discrimination/files/roma_czech_republic_strategy_en.pdf, [cit. 5.1. 2014].

Koopmans, R. - Muis, J. (2009). The rise of right-wing populist Pim Fortuyn in the Netherlands: A discursive opportunity approach. European Journal of Political Research, roč. 48, č. 5, s. 642-664. DOI: 10.1111/j.14756765.2009.00846.x

Koopmans, R. - Statham, P. (1999). Ethnic and Civic Conceptions of Nationhood and the Differential Success of the Extreme Right in Germany and Italy. In Giugni, M. - McAdam, D. - Tilly, Ch. (eds.) How Social Movements Matter. Minneapolis: University of Minnesota Press, s. 225-251.

Koopmans, R. - Olzak, S. (2004). Discursive Opportunities and the Evolution of Right-Wing Violence in Germany. American Journal of Sociology, roč. 110, č. 1, s. 198-230. DOI: 10.1086/386271

Kř̌ž̌ková, M. (2007). Dynamika obrazu uprchlikei v médićch [online]. Multikulturní centrum Praha, Cizinci, našinci a media. Dostupné z: http://www.mkc.cz/uploaded/download/Cizinci_nasinci_a_media.pdf, [cit. 27. 3. 2013].

Křížková, M. (2012). Analýza mediálního zobraz̧eni Romi v českých médiúch od začátku července 2011 do konce kvètna 2012 [online]. Dostupné z: www.romea.cz/dokumenty/med_an_FINAL.doc, [cit. 19. 4. 2013].

Larson, G. S. (2005). Media \& Minorities: The Politics of race in news and Entertainment. Lanham, MD: Rowman \& Littlefield.

Liégeois, J. P. (2008). Roma in Europe. Stationary Office Books: Council of Europe.

Mafra. MF Dnes. 2011, roč. 22, č. 187-214. Praha: MaFra, a.s.

Nekvapil, J. -Leudar, I. (2003). Diskuse o migračním zákonu v českých masmédiích na počátku roku 1993. In: Homoláč, J. - Karhanová, K. - Nekvapil, J. (eds.). Obraz Romů v strédoevropských masmédiích po roce 1989. Praha, s. 6-34.

Pietikaeinen, S. (2003). Indigenous Identity in Print: Representations of the Sami in News Discourse. Discourse \& Society, roč 14, č. 5, s. 581-609.

Pietikaeinen, S. - Hujanen J. (2003). At the crossroads of ethnicity, place and identitiy: Representations of northern people and regions in Finnish news discourse. Media, Culture \& Society, roč. 25, č. 2, s. 251-268. 
Rada Európy (2012). Estimates on Roma population in European Countries. [online]. Dostupné z: http://hub.coe.int/c/document_library/get_file?uuid=3f6c4a82-0ca7-4b80-93c1fef14f56fdf8\&groupId=10227, [cit. 5. 1. 2014].

Richardson, J. E. (2004). (Mis)representing Islam: the Racism and Rhetorics of British Broadsheet Newspapers. Amsterdam: John Benjamins Publishing Company.

Ringier. Blesk, roč. 20, č. 187-214. Praha: Ringier.

Samková, K. A. (2012). Dopis pro prezidenta PČR, plk. Mgr. Petr Lessyho. Stížnost na aprisob vyšstrováni tžv. "mačetovébo útoku" $v$ Novém Borua souvisejicí úvaby [online]. Dostupné z: http://www.macetovyutok.cz/index.php?r=post/view\&id=71, [cit. 11. 8. 2013].

Snow, D. A. - Benford, R. D. (1988). Ideology, Frame Resonance and Participant Mobilization. International Social Movement Research, roč. 1, ̌́. 1, s. 197-217.

Tejkalová, A. -Láb F. (2009, et al.). Analýza mediálního spracováni vybranjich kauz týkajicich se etnických menšin [online]. Dostupné z: http://minority.fsv.cuni.cz/uploads/MENSINY_ANALYZA.pdf, [cit. 12. 6. 2013].

Teo, P. (2000). Racism in the news: A Critical Discourse Analysis of news reporting in two Australian Newspapers. Discourse \& Society, roč. 11, č. 1, s. 7-49.

Unie Vydavatelů (2011). Media Projekt 2011 3. čturtletí + 4. čturtletí [online]. Dostupné z: http://www.unievydavatelu.cz/Upload/978.pdf, [cit. 14. 4. 2013].

Van Dijk, T. A. (1991) Racism and the Press. London: Routledge.

Van Dijk, T. A. (1992). Discourse and the Denial of Racism. Discourse \& Society, roč. 3, č. 1, s. 87-118.

Van Dijk, T. A. (2006). Racism and the press in Spain. In: Blas, José, L. - Casanova, M. - Velando, M. Vellón J. (eds.). Discurso y Sociedad II. Nuevas contribuciones al estudio de la lengua en un contexto social. Castelló de la Plana: Universitat Jaume I, s. 59-99.

Van Dijk, T. A. (2007). The study of discourse: an introduction. In: Van Dijk, T. A. (Ed.). Discourse Studies (Sage Benchmarks in Discourse Studies). London: Sage, s. xix-xii.

Vaňo, B. -Haviarová, E. (2002). Demografické trendy rómskej populácie. In: Vašečka, M. (Ed.) ČAČIPEN PAL O ROMA. Súbrnná správa o Rómoch na Slovensku, s. 475-502. [online]. Dostupné z: http://www.ivo.sk/buxus/docs//publikacie/subory/suhrnna_sprava_o_romoch_na_slovensku.pdf, [cit. 5. 1. 2014].

Vláda České republiky (20120. Zpráva o stavu romské menšiny v ČR za rok 2011 [online]. Dostupné z: http://www.vlada.cz/assets/ppov/zalezitosti-romske-komunity/aktuality/III_Zprava_2011_def.doc, [cit. 20. 6. 2013].

Wodak R. (2008). Introduction: Discourse Studies - Important Concepts and Terms. In: Wodak, R. Krzyzanovski, M. Qualitative Discourse Analysis in the Social Sciences.. London: Palgrave Macmillan, s. 1-29.

Wodak, R., Pelinka, A. (2002). The Haider Phenomenon in Austria. New Jersey: Transaction Publishers. 
Alena Kluknavská, Lenka Zagibová: Neprispôsobiví Rómovia a slušná väčšina?

\section{Unadaptable Roma and the decent majority? News discourse after violent incidents in the north of the Czech Republic in 2011}

\section{SUMMARY}

The paper analyses the news discourse on the Roma minority during the violent incidents and the following anti-Roma protests in the north of the Czech Republic in 2011. It focuses on news reports relating to the Roma in the three most-read Czech newspapers (Právo, MF Dnes a Blesk) between August 8, 2011 and September 8, 2011. Tensions in the region arose after Roma attacks on members of the non-Roma majority in a local bar in the city of Nový Bor. The incident contributed to (already) negative attitudes towards the Roma minority and anti-Roma rhetoric became prevalent not only in statements made by the far right, but also in statements made by some local politicians and the general public. The study adheres to discourse analysis and is undertaken in three stages. In the first stage we introduce a general characterization of the news and the context of the unrest as presented by the media. This is followed by an analysis of the extent to which the media emphasized ethnicity in the conflict and generalized "Roma" criminality. In the third stage the dichotomy in relation to the non-Roma majority and the Roma minority (us vs. them) is analysed.

The analysis points to the systematic "othering" and stereotyping of the Roma minority in the selected newspapers. The results show that newspapers emphasized the ethnicity of Roma actors involved in the attacks and generalized the given incidents as continuing "Roma" criminality, implying a link between the deteriorating security situation and the perceived aggressiveness of the Roma minority. In other words, the news discourse projected the criminal actions of individuals, i.e. Roma individuals, onto the broader group of a people, i.e. the Roma minority. Moreover, the newspapers tended to present the situation either as "the last drop" with respect to the tensions between the two separate groups (the majority non-Roma population and the Roma minority) or as a consequence of problems with the criminality of "unadaptable" citizens, meaning the Roma. References to Roma ethnicity were emphasized to the point where a causal link between the Roma and criminality was implied. Such a discursive strategy tends to shift "the Others" - in this case, the Roma community - away from "us", i.e. mainstream society.

The analysed sample of news reports was directly or indirectly related to criminal acts or protests; hence, it is not surprising that the Roma were portrayed in relation to criminality and violence. However, the media emphasized the ethnicity of the actors even in those cases when such a categorization was not necessary. Moreover, the Roma as a group were blamed not only for particular acts, but also for increased criminality in the region generally. Since the actions of individuals were generalized to the whole minority, newspapers thus reinforced the perception of collective guilt, with all Roma treated as a homogenous entity. The media also built up majority-minority differences between the groups. The systematic categorization of Roma as "the Others" was visible in the newspapers on two levels: 1) the explicit labelling of the two groups - the (nonRoma majority) residents and the Roma, and 2) the more implicit naming of the two groups - the natives and the unadaptables. Although the second level was supposed to be objective and ethnically neutral, it correlated with the Whites on the one hand and Roma on the other. The results also showed that the Roma were cited considerably less than the majority population and the authorities, and then often anonymously, e.g. "the Roma say", "A Roma woman states", "The Roma in the village claim", etc. The way in which this 
dichotomous division was presented created a frame in which the "decent" majority suffered at the hands of the unadaptable Roma minority.

Categorization of the attackers as Roma not only puts the minority into a certain ethnic scheme, but also affects attitudes and behaviour to the Roma minority as a whole. The idea of attackers can create a discursive frame in which the aggressors represent not individuals, but all Roma criminals. Such a strategy can lead to a deepening of racial stereotypes in society, and can also contribute to the formation of a favourable discursive opportunity structure, hence a favourable context for parties of the far right, which are characterised by their nationalistic, racist and xenophobic rhetoric and actions. The far right Worker's Party of Social Justice (DSSS) framed the incidents as the justified anger of "ordinary people", whose rights were oppressed by an unadaptable minority. The news discourse in relation to the Roma minority provided fertile territory for the far right, which builds on the animosities toward various perceived "enemies", in this case the Roma minority. This, in turn, can lead to political acceptance of antiziganism in the public discourse.

The success of a political party or movement in setting the agenda is, however, influenced by other factors as well. It might be dependent on factors linked not only to discursive opportunities, but also to the resonance of frames with the public or to the structures of political opportunities. In some countries, such as Estonia or Latvia, far right parties are not successful because mainstream parties to a large extent have adopted the radical rhetoric of far right movements and parties. In contrast, in the Czech Republic, the popularity of the far right DSSS, for example, has increased mainly in those regions where the public was more inclined to accept racialist explanations for the unrest offered by the party. The far right People's Party Our Slovakia (LSNS) adopted a similar strategy and was locally successful in parliamentary elections 2010 and 2012 (and in elections to the bodies of self-governing regions in 2013) in regions with perceived problematic relations between the non-Roma majority and the Roma minority.

The results presented in this study are consistent with previous research on the coverage of minorities in news media and provide empirical evidence from a case in the Czech Republic. The findings suggest that future research could be directed at a comparison of various cases not only in the Czech Republic and among countries, but also at a comparison of the coverage of such cases by national and regional/local news. 